Check for updates

Cite this: RSC Adv., 2017, 7, 44272

Received 2nd August 2017

Accepted 6th September 2017

DOI: $10.1039 / c 7 r a 08543 e$

rsc.li/rsc-advances

\section{Ternary Eu(III) and Tb(III) $\beta$-diketonate complexes containing chalcones: photophysical studies and biological outlook $\dagger$}

\begin{abstract}
Zafar Abbas, Srikanth Dasari and Ashis K. Patra (D)*
Four ternary lanthanide(III) complexes, namely $\left[\mathrm{Eu}(\mathrm{Anpp})(\mathrm{TTA})_{3}\right](1),\left[\mathrm{Tb}(\mathrm{Anpp})(\mathrm{TTA})_{3}\right](2),\left[\mathrm{Eu}(\mathrm{Pypp})(\mathrm{TTA})_{3}\right](3)$ and $\left[\mathrm{Tb}(\mathrm{Pypp})(\mathrm{TTA})_{3}\right]$ (4), [TTA = 1,1,1-trifluoro-3-(2-theonyl)acetone, Anpp = 3-(anthracen-9-yl)-1(pyridine-2-yl)prop-2-en-1-one, Pypp = 3-(pyren-1-yl)-1-(pyridine-2-yl)prop-2-en-1-one] were designed, synthesized and characterized by various spectroscopic techniques like $\mathrm{FT}-\mathrm{IR},{ }^{1} \mathrm{H}-\mathrm{NMR}$, ESI-MS, UV-Vis and spectral emission studies. [Eu(Pypp)(TTA) $]_{3}$ (3) was structurally characterized, showing an eight coordinated $\left\{\mathrm{EuN}_{1} \mathrm{O}_{7}\right\}$ square antiprismatic geometry with one $\mathrm{N}, \mathrm{O}$-donor chalcone and three $\mathrm{O}, \mathrm{O}$-donor $\beta$-diketonate ligands. Detailed photophysical properties like excited state lifetime $(\tau)$ and hydration number $(q)$ were determined. The presence of three TTA ligands inhibits non-radiative deactivation with lifetimes in $\mathrm{H}_{2} \mathrm{O}$ in the range of $0.306-0.445 \mathrm{~ms}$. The calculated hydration number $(q)$ values (0.37-0.63) from the excited state lifetime measurements show the absence of any bound $\mathrm{H}_{2} \mathrm{O}$ molecules in the coordinatively saturated complexes $(q<1)$. Complexes 1-4 were studied for their biological interactions with DNA and protein and their DNA photocleavage activity was investigated. The binding constants with CT-DNA $\left(K_{\mathrm{b}}=1.15-8.8 \times 10^{5} \mathrm{M}^{-1}\right)$ and HSA $\left(K_{\mathrm{HSA}}=6.5-8.1 \times 10^{5} \mathrm{M}^{-1}\right)$ of complexes 1-4 show their significant affinity towards these biological targets. Incorporation of chalcone ligands containing anthracene or pyrene as a photosensitizing moiety in these complexes were effective in generating reactive oxygen species (ROS). Complexes 1-4 display moderate photocleavage of supercoiled (SC)-DNA to its nicked circular (NC) form on exposure to UV-A light of $365 \mathrm{~nm}$ through the generation of singlet oxygen $\left({ }^{1} \mathrm{O}_{2}\right)$ and hydroxyl radicals $\left({ }^{\circ} \mathrm{OH}\right)$ under physiological conditions.
\end{abstract}

\section{Introduction}

Lanthanide complexes have been widely explored as sensors, MRI contrast agents, responsive optical probes, luminescent MOFs, display materials, chemo and radio therapeutic agents, and cellular imaging agents owing to their intricate optical properties and high redox stability of the trivalent $\mathrm{Ln}^{3+}$ state. ${ }^{1-11}$ Lanthanides are used abundantly in various industries like optical, lighting, display, laser, ceramics, energy or non-invasive imaging technologies. The very fascinating optical features of the lanthanide ions originate from their [Xe] $4 \mathrm{f}^{n}(n=0-14)$ electronic configuration because of shielded f-orbitals by the filled $5 \mathrm{~s}$ and $5 \mathrm{p}$ orbitals, giving rise to various electronic levels of defined energy which are hardly sensitive to the surrounding chemical environment. The $\mathrm{f}-\mathrm{f}$ transitions are symmetry

Department of Chemistry, Indian Institute of Technology Kanpur, Kanpur 208016, Uttar Pradesh, India. E-mail: akpatra@iitk.ac.in

$\dagger$ Electronic supplementary information (ESI) available: ESI-MS figures; unit cell packing diagram; selected bond distances and angles; photophysical aspects; lifetime measurements; DNA and protein binding plots; DNA cleavage data. CCDC 1566126. For ESI and crystallographic data in CIF or other electronic format see DOI: $10.1039 / \mathrm{c} 7 \mathrm{ra08543e}$ forbidden and have very weak absorption $\left(\varepsilon \sim 0.1-1 \mathrm{M}^{-1} \mathrm{~cm}^{-1}\right)$, therefore resulting in very faint luminescence, which can be enhanced by attachment of a suitably chosen organic chromophore to excite the lanthanide by the so called 'antenna effect', which provides a large Stokes shift and avoids photobleaching. ${ }^{4,5}$ Such indirect sensitization in fact relaxes the strict selection rules that otherwise limit the $\mathrm{f} \rightarrow \mathrm{f}$ transitions in $\mathrm{Ln}^{3+}$ and results in significant luminescence enhancement. Currently polyaminocarboxylate gadolinium complexes, namely gadopentatic acid (Magnevist ${ }^{\circledR}$ ) and gadoteric acid (Artirem ${ }^{\circledR}$ ) are in clinical use as magnetic resonance imaging (MRI) contrast agents, showing promising role of the lanthanides in biomedical imaging. ${ }^{12}$ Photodynamic therapy is now being widely appreciated as a promising noninvasive methodology for curb and cure of cancer which relies on the generation of cytotoxic reactive oxygen species (mainly ${ }^{1} \mathrm{O}_{2}$ ) by irradiating some nontoxic photosensitizers at a specific wavelength, that causes cell death in the region of irradiation. ${ }^{13-15}$ Photofrin ${ }^{\circledR}$, the first clinically accepted PDT agent, is an oligomeric mixture of natural hematoporphyrin, generates reactive oxygen species $\left({ }^{1} \mathrm{O}_{2}\right)$ in a type II energy transfer pathway at $633 \mathrm{~nm} \cdot{ }^{\mathbf{1 4 - 1 6}}$ Weak absorbance in phototherapeutic window, prolonged skin sensitivity and hepatotoxicity are the major drawbacks with 
porphyrin-based PDT agents. ${ }^{17,18}$ Although there are several transition metal complexes in the literature showing remarkable photocytotoxicity and DNA photocleavage activity, very few are reported with lanthanides. ${ }^{19-24}$ Lanthanide(III) complexes with a range of coordination numbers ranging from 7-12 and unusual optical properties will be niche in the development of efficient photocytotoxic agents and the excellent redox stability of $\operatorname{Ln}$ (III) is also beneficial for their use in biological media against various reducing agents in biology like thiols and ascorbates. Some of the Ln(III) ions have the advantage of bright visible light luminescence over other lanthanides and transition metals and they have been widely explored as sensors in physiological conditions or in bioassays. ${ }^{4-7}$ Currently we are exploring luminescent $\mathrm{Ln}(\mathrm{III})$ complexes for their interaction with biological targets, photoinduced DNA cleavage activity and cellular imaging agents. ${ }^{24}$

We describe here, four lanthanide complexes of $\mathrm{Eu}(\mathrm{III})$ and $\mathrm{Tb}(\mathrm{III}) \quad$ viz. $\quad\left[\mathrm{Eu}(\mathrm{Anpp})(\mathrm{TTA})_{3}\right] \quad(\mathbf{1}), \quad\left[\mathrm{Tb}(\mathrm{Anpp})(\mathrm{TTA})_{3}\right] \quad$ (2), $\left[\mathrm{Eu}(\mathrm{Pypp})(\mathrm{TTA})_{3}\right](3)$ and $\left[\mathrm{Tb}(\mathrm{Pypp})(\mathrm{TTA})_{3}\right](4)[\mathrm{TTA}=1,1,1-$ trifluoro-3-(2-theonyl)acetone, Anpp = 3-(anthracen-9-yl)-1(pyridine-2-yl)prop-2-en-1-one, $\quad$ Pypp $=3$-(pyren-1-yl)-1(pyridine-2-yl)prop-2-en-1-one], were synthesized, characterized and studied for their photophysical properties and interaction with DNA and serum proteins along with photoinduced DNA cleavage activity. The complexes containing three anionic $\beta$-diketonate ligand and one bidentate chalcone conjugated to a flurophore have been designed as coordinatively saturated systems to avoid non-radiative transitions from the Ln(III) excited states through vibrational energy transfer (VET) to O-H, $\mathrm{N}-\mathrm{H}$ and $\mathrm{C}-\mathrm{H}$ oscillators (Scheme 1).,2,4,7,25 The $\beta$-diketonate ligands having various conjugated aromatic planar groups are established as efficient sensitizers in developing visible light emitting lanthanide $\left(\mathrm{Eu}^{3+}, \mathrm{Sm}^{3+}\right.$ and $\left.\mathrm{Tb}^{3+}\right)$ complexes. Use of polyfluorinated $\beta$-diketonates have the advantage over nonfluorinated ones because of the vibrational energy of the $\mathrm{C}-\mathrm{H}$ oscillator $\left(\nu=2800-3000 \mathrm{~cm}^{-1}\right)$ is higher than that of C-F oscillator $\left(\nu=1120-1350 \mathrm{~cm}^{-1}\right)$. Fluorination induced inductive

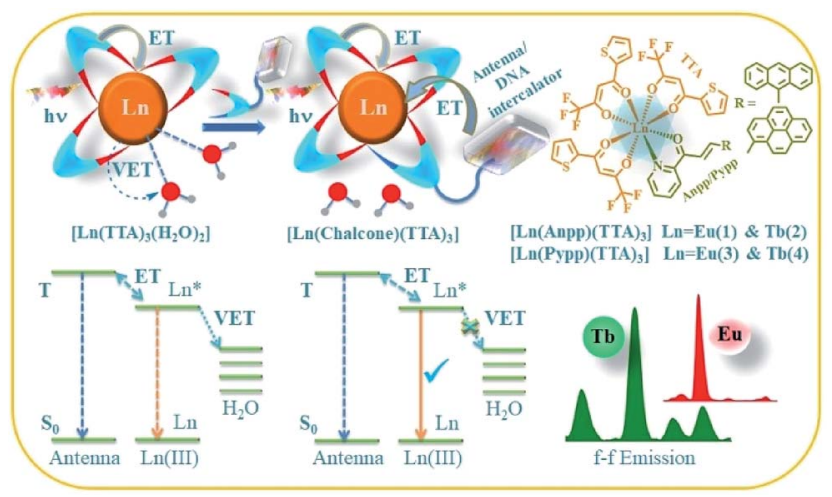

Scheme 1 Schematic design principle for complexes 1-4 showing deactivation of $\operatorname{Ln} *$ in $\left[\operatorname{Ln}(T T A)_{3}\left(\mathrm{H}_{2} \mathrm{O}\right)_{2}\right.$ ] via nonradiative vibrational energy transfer (VET) through lanthanide coordinated $\mathrm{H}_{2} \mathrm{O}$ (left); incorporation of bidentate chalcones inhibit this quenching with increased emission intensity (middle) and representation of [ $\mathrm{Ln}\left(\right.$ chalcone) $\left.(T \mathrm{TA})_{3}\right]$ (1-4) with luminescence from of $\mathrm{Eu}^{3+}$ and $\mathrm{Tb}^{3+}$ (right). effect of highly electron withdrawing $-\mathrm{CF}_{3}$ group decreases the non-radiative loss of $\operatorname{Ln}(\mathrm{III})$ excited state energy compared to the high energy $\mathrm{C}-\mathrm{H}$ oscillators, resulting in enhanced luminescence intensity and rigidity of the complexes due to tight bond between ligand and $\operatorname{Ln}(\mathrm{III}){ }^{26,27}$ The choice of two different chalcones as secondary ligands having $\alpha, \beta$-unsaturated ketone as central core conjugated to anthracene or pyrene as light harvesting photosensitizing moiety. Chalcones show various biological effects like anti-inflammatory, anticancer, antimalarial, antifungal, anti-infective activity and some other features like sensing to non-linear optics. ${ }^{28-33}$ Moreover these moieties can also act as DNA intercalators and photosensitizers. We have evaluated biological interaction of complexes 1-4 with nucleic acid and protein. They show good binding affinity towards dsDNA through the intercalation of planar aromatic pyrene and anthracene moieties between the DNA base pairs. HSA binding affinity was determined by quenching in emission of Trp-214 residue. They exhibit photoinduced DNA photocleavage activity through the generation of singlet oxygen $\left({ }^{1} \mathrm{O}_{2}\right)$ in Type-II pathways and $\mathrm{OH}$ involving photoredox pathway at physiological conditions.

\section{Results and discussion}

\section{Synthesis and general aspects}

Herein, we have synthesized two chalcone derivatives namely Anpp [(E)-3-(anthracen-9-yl)-1-(pyridin-2-yl)prop-2-en-1-one $]$ and Pypp [(E)-3-(pyren-1-yl)-1-(pyridin-2-yl)prop-2-en-1-one] by Claisen-Schmidt condensation reaction and characterized by ${ }^{1} \mathrm{H}-\mathrm{NMR}$, UV-Vis and ESI-MS studies. ${ }^{34,35}$ Four TTA-based lanthanide complexes containing these chalcones were then synthesized by reacting a solution of $\operatorname{Ln}(\mathrm{TTA})_{3} \cdot 2 \mathrm{H}_{2} \mathrm{O}$ in THF with chalcones (Scheme 2). Complexes were isolated in good yields and characterized by FT-IR, ESI-MS, UV-Vis and emission spectroscopy and through structural determination of complex 3 by single crystal X-ray crystallography. FT-IR spectra shows a lowering in frequency in the stretching vibrations of $\mathrm{C}=\mathrm{O}$ and $\mathrm{C}=\mathrm{C}$ bonds from 1676 and $1632 \mathrm{~cm}^{-1}$ in the free HTTA to around 1600 and $1535 \mathrm{~cm}^{-1}$ in the complexes 1-4 while the bands at $490 \mathrm{~cm}^{-1}$ correspond to $\nu_{\mathrm{Ln}-\mathrm{O}}$ stretching vibrations and at $519 \mathrm{~cm}^{-1}$ to Ln-N stretching vibrations. ${ }^{26 b, 26 c, 36,37}$ ESI-MS spectra of the complexes $\mathbf{1}, \mathbf{2}$ and $\mathbf{4}$ assignable to [M-TTA $]^{+}$and for complex 3 to $[\mathrm{M}-\mathrm{Na}]^{+}$in DMF with matching isotopic distribution profiles indicating the formation of complexes 1-4 (Fig. S1, ESI†े).

The UV-Vis absorption spectra of the complexes show the ligand-centered absorption band corresponding to $\pi-\pi^{*}$ transitions in the range of 270 to $480 \mathrm{~nm}$. Complexes 1 and 2 containing Anpp ligand displayed close resemblance in their absorption spectra with $\lambda_{\max }$ at $270 \mathrm{~nm}$ and $346 \mathrm{~nm}$ originated from the Anpp and TTA ligands. On the contrary, complexes 3 and 4 with Pypp ligands shows overlapping spectra with $\lambda_{\max }$ at $273 \mathrm{~nm}, 346 \mathrm{~nm}$ and $440 \mathrm{~nm}$ originated from the Pypp and TTA ligands (Fig. 1(a), S2 and S3 in ESI†). Close resemblance in the UV-Vis spectra of 1-4 with identical ligands is independent of Ln(III), also suggests minimal or no perturbation of the electronic levels of $\operatorname{Ln}(\mathrm{III})$. Absorption spectra of the complexes 1-4 


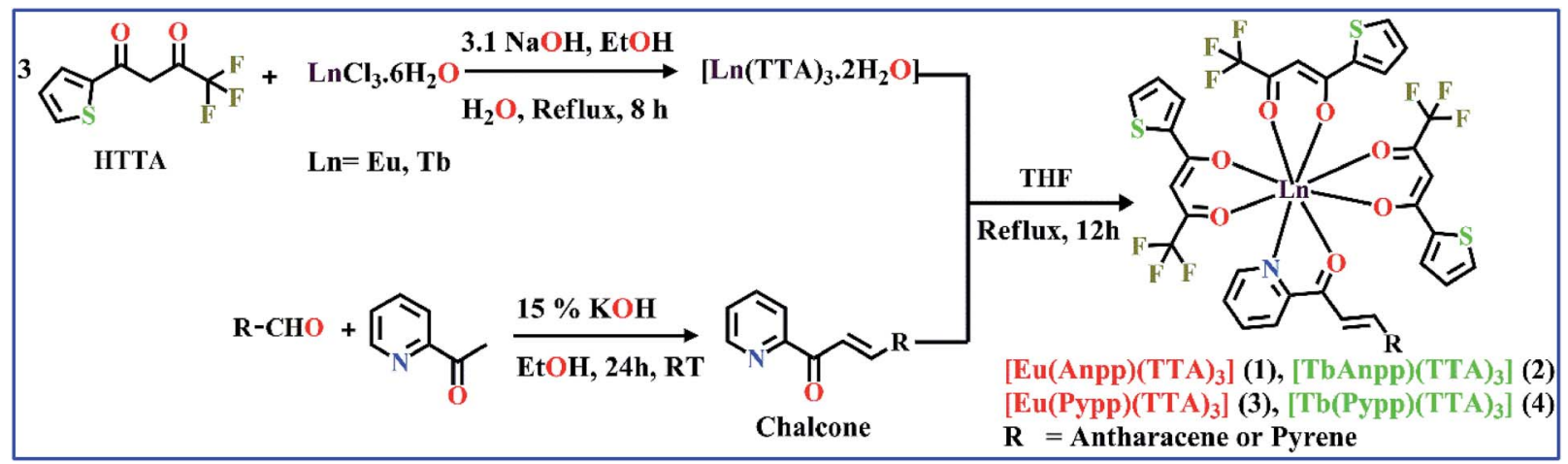

Scheme 2 Synthetic route for the chalcone ligands and [ $\mathrm{Ln}\left(\right.$ chalcone) $\left.(\mathrm{TTA})_{3}\right](1-4)$ complexes.
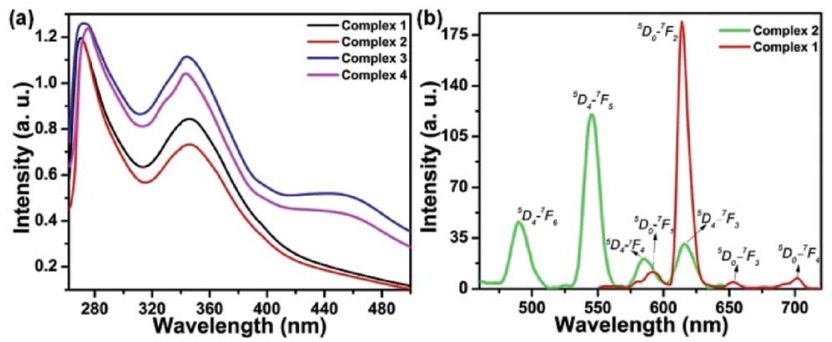

Fig. 1 (a) UV-visible absorption spectral traces of complexes 1-4 ([1] and [2] $=20 \mu \mathrm{M}$, [3] and [4] = $15 \mu \mathrm{M}$ ) in DMF at $298 \mathrm{~K}$. (b) Time-delayed luminescence spectra for complexes 1 and 2 at $298 \mathrm{~K}$. [delay time $=$ $0.1 \mathrm{~ms}$, gate time $=0.1 \mathrm{~ms}, \lambda_{\mathrm{ex}}=340 \mathrm{~nm}$, slit width $=10 \mathrm{~nm}$, [1] and [2] $=20 \mu \mathrm{M}$.

in DMF recorded for a period of $4 \mathrm{~h}$ at $298 \mathrm{~K}$ shows no appreciable change in the band intensity suggesting their stability in solution state (Fig. S4, ESI $\dagger$ ).

\section{Photophysical properties}

Time-delayed luminescence spectra of the complexes shows emission bands corresponds to ${ }^{5} \mathrm{D}_{0} \rightarrow{ }^{7} \mathrm{~F}_{J}(J=0-4)$ and ${ }^{5} \mathrm{D}_{4} \rightarrow$ ${ }^{7} \mathrm{~F}_{J}(J=6-3)$ transitions for $\mathrm{Eu}^{3+}$ and $\mathrm{Tb}^{3+}$ respectively (Fig. 1(b)). Excited state lifetime of the complexes in $\mathrm{H}_{2} \mathrm{O}$ were found in the range of $0.306 \mathrm{~ms}$ to $0.445 \mathrm{~ms}$ are depicted in Table 1 (Fig. S5, ESI $\dagger$ ).

Table 1 Selected physiochemical and photophysical data for complexes 1-4

\begin{tabular}{llllll}
\hline Complexes & $\mathrm{IR}^{a}\left(\mathrm{~cm}^{-1}\right) \nu_{\mathrm{C}=\mathrm{O}}$ & $\tau_{\mathrm{DMF}}{ }^{b}(\mu \mathrm{s})$ & $\tau_{\mathrm{H}_{2} \mathrm{O}}{ }^{c}(\mu \mathrm{s})$ & $\tau_{\mathrm{D}_{2} \mathrm{O}}{ }^{d}(\mu \mathrm{s})$ & $q^{e}$ \\
\hline Complex 1 & $1601(\mathrm{~s})$ & 464 & 445 & 633 & 0.50 \\
Complex 2 & $1603(\mathrm{~s})$ & 420 & 395 & 426 & 0.62 \\
Complex 3 & $1602(\mathrm{~s})$ & 457 & 390 & 560 & 0.63 \\
Complex 4 & $1602(\mathrm{~s})$ & 391 & 306 & 319 & 0.37
\end{tabular}

${ }^{a}$ IR vibrational stretching frequency in $\mathrm{KBr}$ phase. ${ }^{b}$ Excited state lifetime $(\tau \pm 15 \%)$ measured in DMF. ${ }^{c}$ Excited state lifetime $(\tau \pm$ $15 \%)$ measured in $\mathrm{H}_{2} \mathrm{O} .{ }^{d}$ Excited state lifetime $(\tau \pm 15 \%)$ measured in $\mathrm{D}_{2} \mathrm{O} .{ }^{e}$ Hydration number $(q \pm 10 \%)$ determined using modified Horrock's equation.
The lower $\tau$ value for complex $\mathbf{4}$ possibly due to the smaller energy gap between the ${ }^{5} \mathrm{D}_{4}$ state of $\mathrm{Tb}^{3+}$ and the triplet excited state of TTA moiety, that may result in thermal back energy transfer processes and consequently an ineffective radiative transition from $\mathrm{Tb}^{3+5} \mathrm{D}_{4}$ excited state. ${ }^{38}$ Solution state speciation of complexes in aqueous media was established by recording their excited state lifetimes in $\mathrm{H}_{2} \mathrm{O}$ and $\mathrm{D}_{2} \mathrm{O}$. Their hydration number $(q)$ was calculated using modified Horrock's equation that gave values less than one, confirming the absence of $\mathrm{H}_{2} \mathrm{O}$ molecule in the complexes summarised in Table 1 (Fig. S6, ESI $\dagger$ ). ${ }^{39}$ Absence of $\mathrm{H}_{2} \mathrm{O}$ molecule at $\mathrm{Ln}$ (III) center arrest the nonradiative vibrational energy transfer (VET) from Ln(III) to $\mathrm{O}-\mathrm{H}$ oscillators of $\mathrm{Ln}(\mathrm{III})$ bound $\mathrm{H}_{2} \mathrm{O}$, thus results in longer lifetimes.

\section{Crystal structure determination}

[Eu(Pypp)(TTA $\left.)_{3}\right]$ (3) have been structurally characterized by single crystal X-ray diffraction studies. It was crystallized in triclinic crystal system with space group $P \overline{1}$ as mononuclear discrete molecule having two molecules in the unit cell. The ORTEP view of complex 3 along with coordination polyhedron of lanthanide core have been shown in Fig. 2. It has an eight coordinated $\left\{\mathrm{EuN}_{1} \mathrm{O}_{7}\right\}$ coordination geometry around the europium centre, two of which originates from a bidentate (a)

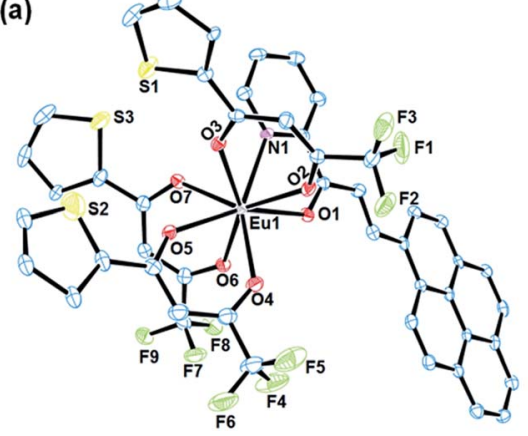

(b)

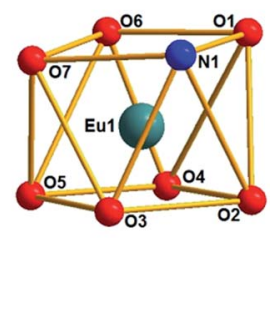

Fig. 2 (a) ORTEP view of [Eu(Pypp)(TTA) 3 (3) with thermal ellipsoids drawn at the $50 \%$ probability level. (b) The $\left\{\mathrm{EuN}_{1} \mathrm{O}_{7}\right\}$ coordination polyhedra of the Eu(II) core showing distorted square antiprism geometry. 
$\mathrm{N}, \mathrm{O}$-donor neutral chalcone ligand and the other six from three monoanionic bidentate $\mathrm{O}, \mathrm{O}$ donor TTA ligands, that can be best described as distorted square antiprismatic geometry. Here each square-plane is constituted from $\mathrm{N} 1, \mathrm{O} 1, \mathrm{O} 6, \mathrm{O} 7$ and $\mathrm{O} 2$, O3, O4, O5 atoms respectively with a dihedral angle of $4.75^{\circ}$ between them (Fig. 2(b)). At the center of the square antiprism lies Eu(III) with a distance of $1.251 \AA$ to the oxygen containing plane and $1.440 \AA$ to the opposite plane for complex 3. Eu-N(1) and $\mathrm{Eu}-\mathrm{O}(1)$ bond lengths of the neutral chalcone were 2.608(6) and 2.453(5) Å respectively. On contrary, Eu-O bond distances from the anionic TTA was found in the range from 2.349(5) to $2.375(6) \AA$. The $\angle \mathrm{N}-\mathrm{Eu}-\mathrm{O}$ bite angle for the chalcone ligand was $62.43(18)^{\circ}$ while $\angle \mathrm{O}-\mathrm{Eu}-\mathrm{O}$ bite angle for TTA ligands were ranging from $71.02(19)-72.15(19)^{\circ}$. All the selected major bond lengths and bond angles have been listed in the Table S1, ESI. $\dagger$ Unit cell packing diagram have been given in Fig. S7 in ESI. $\dagger$

\section{DNA binding studies}

For the development of potential chemotherapeutic agents, DNA has been the primary biological target of many pharmacologically active drugs. These drug molecules mainly bind with the target either through covalent or noncovalent interactions. There have been two major classes of noncovalent DNA binding agents: intercalators and groove binders. Intercalation involves the insertion of planar moiety between the DNA base pairs, resulting a decrease in DNA helical twist and its elongation whereas groove binding does not affect large conformational changes which fit into the major or minor grooves of DNA. ${ }^{\mathbf{4 0 , 4 1}}$
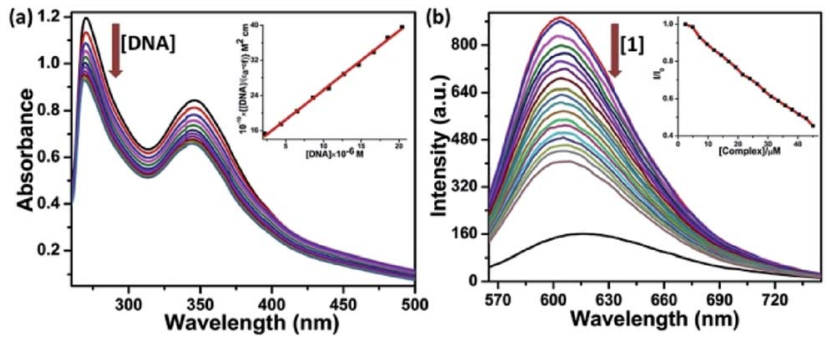

Fig. 3 (a) UV-visible traces for [Eu(Anpp)(TTA) 3 ] $(20 \mu \mathrm{M})$ in $5 \mathrm{mM}$ Tris buffer ( $\mathrm{pH}$ 7.2) with increasing [CT-DNA] at $298 \mathrm{~K}$; inset: [DNA] $/ \Delta \varepsilon_{\text {af }}$ versus [DNA] plot for complex 1. (b) Emission spectral traces for EBbound CT-DNA with increasing concentration for complex 1 in $5 \mathrm{mM}$ Tris buffer $(\mathrm{pH} 7.2) 298 \mathrm{~K}$; $\lambda_{\text {ex }}=546 \mathrm{~nm}, \lambda_{\mathrm{em}}=603 \mathrm{~nm}$, [DNA] $=$ $212 \mu \mathrm{M},[E B]=12 \mu \mathrm{M}$; inset: a plot of $/ / I_{0} \mathrm{vs}$. [complex 1 ].
Electronic absorption spectral studies. DNA binding interaction studies of the complexes were carried out through UV-Vis absorption spectral titration. Absorption spectra was recorded with increasing concentration of CT-DNA at a constant complex concentration in order to determine the intrinsic binding constant $K_{\mathrm{b}}$ in $5 \mathrm{mM}$ Tris HCl-NaCl buffer ( $\mathrm{pH}=7.2$ ) (Fig. 3(a) and S8-S10 in ESI $\dagger$ ). Significant hypochromism of ligandcentered bands was observed with the addition of CT-DNA, indicative of an intercalative binding mode of the complexes through stacking of planar aromatic chromophore (Anpp and Pypp) between the base pairs of DNA. The $K_{\mathrm{b}}$ values of the order of $10^{5} \mathrm{M}^{-1}$, suggests a strong binding affinity of the complexes 1-4 with DNA (Table 2).

Ethidium bromide displacement studies. Ethidium bromide (EB), a planar cationic dye, which is capable of binding with dsDNA via intercalation between the base pairs. A competitive binding assay of the complexes 1-4 with CT-DNA was performed by recording the changes in emission intensity of EB-DNA adduct by incremental addition of complexes. Fluorescence emission of EB in buffer is quite weak because of the quenching from the solvation. Addition of DNA results in $\sim 25$ fold increase in emission intensity due to stacking of phenanthridine moiety between the base pairs. ${ }^{\mathbf{4 2 , 4 3}}$ Apparent DNA binding constant $\left(K_{\text {app }}\right)$ was calculated from eqn (2) by calculating concentration required for $50 \%$ quenching $\left(C_{50}\right)$ in emission of the EB-DNA adduct (Fig. 3(b) and S11-S13 in ESI $\dagger$ ). The values of $K_{\text {app }}$ shown in Table 2 was in the range of $\sim 10^{7} \mathrm{M}^{-1}$, displayed a significantly strong binding of the complexes with DNA by displacing EB from DNA.

\section{Human serum albumin (HSA) binding studies}

Serum albumin is the most abundant protein in human blood plasma (around $40 \mathrm{mg} \mathrm{mL}^{-1}$ ), has been among the most widely studied proteins. It has very crucial role as a transporter of a variety of fatty acids and capable of binding effectively with metabolites and drug molecules, therefore governing the distribution of such entities in plasma. ${ }^{44}$ The binding of complexes 1-4 was investigated using native tryptophan emission quenching. The emission of HSA is mainly because of the tryptophan residue (Trp-214) located in a hydrophobic environment. Fig. 4 shows the quenching of emission intensity along with hypsochromic shift upon gradual increasing concentration of the complexes at $\lambda_{\mathrm{ex}}=295 \mathrm{~nm}$. The observed spectral changes reveals that the binding of complexes leads to a change in the secondary structure of the protein through

Table 2 Binding parameter for the complexes 1-4 with CT-DNA and HSA

\begin{tabular}{lcccc}
\hline Complexes & $K_{\mathrm{b}} / \mathrm{M}^{-1 a}\left(\times 10^{5}\right)$ & $K_{\mathrm{app}} / \mathrm{M}^{-1 b}\left(\times 10^{7}\right)$ & $K_{\mathrm{HSA}} / \mathrm{M}^{-1 c}\left(\times 10^{5}\right)$ & $n^{d}, \mathrm{~K} / \mathrm{M}^{-1 e}\left(\times 10^{5}\right)$ \\
\hline Complex 1 & $1.15 \pm 0.03$ & 3.56 & $7.3 \pm 0.04$ & $0.69,2.5$ \\
Complex 2 & $8.8 \pm 0.07$ & 3.77 & $6.5 \pm 0.02$ & $0.72,3.6$ \\
Complex 3 & $1.64 \pm 0.11$ & 3.59 & $8.1 \pm 0.03$ & $0.79,9.3$ \\
Complex 4 & $3.68 \pm 0.10$ & 3.65 & $7.1 \pm 0.03$ & $0.71,3.5$
\end{tabular}

${ }^{a} K_{\mathrm{b}}$ : intrinsic DNA binding constant. ${ }^{b} K_{\mathrm{app}}$ : apparent DNA binding constant. ${ }^{c} K_{\mathrm{HSA}}$ : Stern-Volmer quenching constant of HSA emission. ${ }^{d} n$ : number of binding sites in protein. ${ }^{e} K$ : HSA binding constant. 

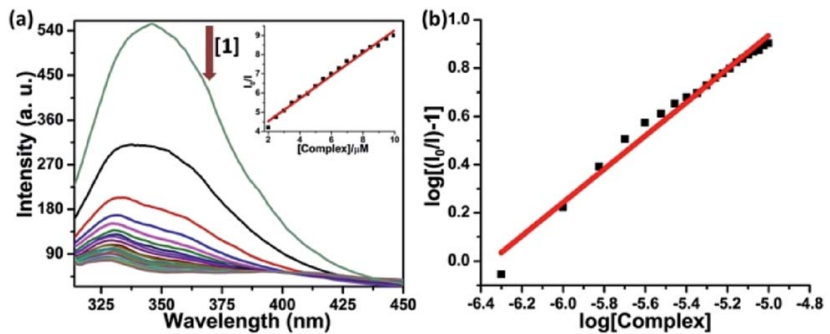

Fig. 4 (a) The emission quenching of HSA on addition of complex 1 in $5 \mathrm{mM}$ Tris buffer (pH 7.2) at $298 \mathrm{~K}$; inset: a plot of $I_{0} / /$ versus [complex 1]; $\lambda_{\mathrm{ex}}=295 \mathrm{~nm}, \lambda_{\mathrm{em}}=345 \mathrm{~nm}$, [HSA] $=5 \mu \mathrm{M}$. (b) Scatchard plot: log $\left[\left(I_{0}-I\right) / /\right]$ vs. log[complex] for HSA in the presence of complex 1.

various hydrophobic interaction, electrostatic interaction, collisional quenching and ground state complex formation. ${ }^{45}$ The dynamic quenching constant $\left(K_{\mathrm{HSA}}\right)$ of the complexes were calculated from the slope of $I_{0} / I v s$. [complex] linear plot using Stern-Volmer equation (eqn (3)). ${ }^{46}$ The values of binding constant $(K)$ and the number of binding sites $(n)$ was obtained from the linear $\log \left(I_{0} / I-1\right) v s$. $\log [$ complex $]$ plot using Scatchard equation (eqn (4)). ${ }^{47}$ The corresponding plots have been shown in Fig. 4 and S14-S16 in ESI $\uparrow$ and values are listed in Table 2. Obtained values of binding constant are of the order $\sim 10^{5} \mathrm{M}^{-1}$ suggesting strong binding affinity of the complexes towards target protein.

\section{Synchronous fluorescence studies}

Synchronous fluorescence spectroscopy study provides crucial information in determining the molecular microenvironment of chromophoric groups in protein cavity. As stated by Miller, change of $\Delta \lambda$, which is the difference of emission and excitation wavelength $\left(\Delta \lambda=\lambda_{\mathrm{em}}-\lambda_{\mathrm{ex}}\right)$ gives the spectra of different nature. If $\Delta \lambda=60 \mathrm{~nm}$, emission spectra will reflect the characteristics of tryptophan (Trp) residue and $\Delta \lambda=15 \mathrm{~nm}$ will suggest the characteristics of tyrosine (Tyr) residue in HSA protein. ${ }^{48}$ The synchronous spectra was recorded with increasing concentration of complexes 1-4 both at $\Delta \lambda=60 \mathrm{~nm}$ and $15 \mathrm{~nm}$. The fluorescence spectra at $\Delta \lambda=60 \mathrm{~nm}$ in Fig. 5(a) and S17(a)S19(a) in ESI $\uparrow$ showing dramatic quenching of emission intensity by $82-87 \%$ without any significant changes in $\lambda_{\mathrm{em}}$ maxima. Similarly, the synchronous spectra at $\Delta \lambda=15 \mathrm{~nm}$ (Fig. 5(b) and
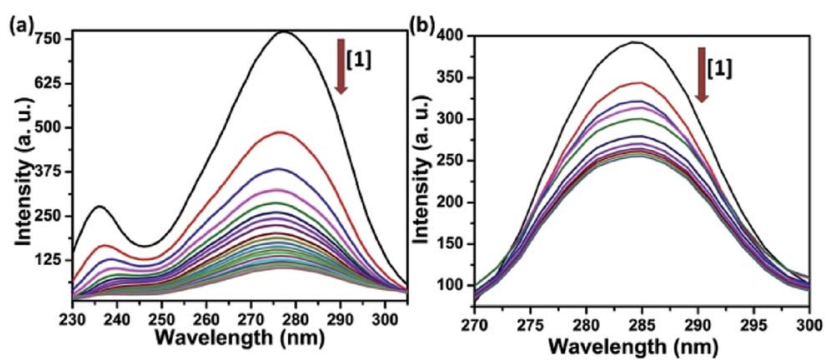

Fig. 5 Synchronous emission spectra of HSA ( $5 \mu \mathrm{M})$ showing effect of increasing concentration of complex 1 (a) with $\Delta \lambda=60 \mathrm{~nm}$ and (b) with $\Delta \lambda=15 \mathrm{~nm}$ at $298 \mathrm{~K}$ in Tris- $\mathrm{HCl}$ buffer $(\mathrm{pH}=7.2)$.
S17(b)-S19(b) in ESI†) showing quenching of emission intensity by $35-40 \%$ with no apparent shift in emission maxima. It is quite obvious from these results that the complexes are affecting the microenvironments of both Tyr and Trp residues, but the effect was much pronounced in microenvironment around Trp. ${ }^{49}$

\section{Photoactivated DNA cleavage activity}

The DNA cleavage activity by photoactivation for the complexes 1-4 was carried out in $5 \mathrm{mM}$ Tris $\mathrm{HCl} / \mathrm{NaCl}$ buffer $(\mathrm{pH}=7.2)$ using supercoiled (SC) pUC19 DNA ( $30 \mu \mathrm{M}, 0.2 \mu \mathrm{g}$ ) by exposing the sample to a radiation of $365 \mathrm{~nm}$ UV-A light by a low power monochromatic lamp $(6 \mathrm{~W})$. The control experiment with only SC-DNA did not displayed any noticeable photocleavage while the ligands HTTA, Anpp and Pypp were showing 6, 9 and $~ 15 \%$ cleavage of SC-DNA (Fig. 6, lanes 1-4). However $\mathrm{EuCl}_{3} \cdot 6 \mathrm{H}_{2} \mathrm{O}$ and $\mathrm{TbCl}_{3} \cdot 6 \mathrm{H}_{2} \mathrm{O}$ were not showing any photocleavage (Fig. 6, lanes 5, 6, 11-14). Complexes 2 and 4 displayed better photocleavage capability compared to 1 and 3 at $40 \mu \mathrm{M}$, mainly due to the possible involvement of the pyrene ring. Treatment of SCDNA with the complexes 1-4 in dark for $1.5 \mathrm{~h}$ did not show any apparent cleavage, rules out the possibility of any hydrolytic cleavage by $\operatorname{Ln}(\mathrm{III})$ complexes.

The groove binding nature of the complexes were also studied utilizing methyl green (MG), which is a major groove binder of SC-DNA and showing $\sim 10 \%$ nicking of SC-DNA. All the complexes bound with SC-DNA showed an inhibition of their DNA photocleavage activity to its nicked circular form in the presence of methyl green reveals the complexes 1-4 are the major groove binders (Fig. 6, lanes 15-19). ${ }^{23 b}$

The mechanism of DNA photocleavage activity of the complexes 1-4 was carried out in order to gain some insight into the process of photocleavage using various additives like ${ }^{1} \mathrm{O}_{2}$ quenchers (L-Histidine, $\mathrm{NaN}_{3}$ ), $\cdot \mathrm{OH}$ scavengers (DMSO, KI, catalase). ${ }^{50-52}$ Photoinduced DNA cleavage reactions mainly involve two ROS-mediated pathways: either via Type-II pathway through ${ }^{1} \mathrm{O}_{2}$ generation or via photoredox pathway that involves 'OH generation. Addition of L-His and $\mathrm{NaN}_{3}$ to SC-DNA as ${ }^{1} \mathrm{O}_{2}$ quenchers, displayed partial inhibition of the photocleavage activity. Photocleavage of DNA by the complexes through ${ }^{1} \mathrm{O}_{2}$ was further confirmed by using $\mathrm{D}_{2} \mathrm{O}$ as solvent showing an enhancement of the cleavage because of the longer lifetime of ${ }^{1} \mathrm{O}_{2}$ in $\mathrm{D}_{2} \mathrm{O}$ than in $\mathrm{H}_{2} \mathrm{O} .{ }^{53}$ Addition of DMSO, $\mathrm{KI}$ and catalase as

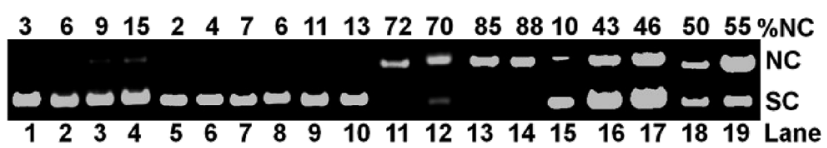

Fig. 6 Photocleavage of SC pUC19DNA (30 $\mu \mathrm{M}, 0.2 \mu \mathrm{g})$ with complexes 1-4 and controls $(40 \mu \mathrm{M})$ in $50 \mathrm{mM}$ Tris- $\mathrm{HCl}$ buffer $(\mathrm{pH} 7.2)$ at $37^{\circ} \mathrm{C}$ for after $1.5 \mathrm{~h}$ exposure with $\mathrm{UV}$-A light $(\lambda=365 \mathrm{~nm}, 6 \mathrm{~W})$. L1: DNA control; L2: DNA + HTTA; L3: DNA + Anpp; L4: DNA + Pypp; L5: $\mathrm{DNA}+\mathrm{EuCl}_{3} \cdot 6 \mathrm{H}_{2} \mathrm{O} ; \mathrm{L6}$ : DNA + $\mathrm{TbCl}_{3} \cdot 6 \mathrm{H}_{2} \mathrm{O} ; \mathrm{L7}: \mathrm{DNA}+1$ (dark); L8: DNA + 2 (dark); L9: DNA + 3 (dark); L10: DNA + 4 (dark); L11: DNA + 1; L12: DNA + 2; L13: DNA + 3; L14: DNA + 4; L15: DNA + MG (methyl green); $L 16: D N A+M G+1 ; L 17: D N A+M G+2 ; L 18: D N A+M G+3$; L19: $D N A+M G+4$ 


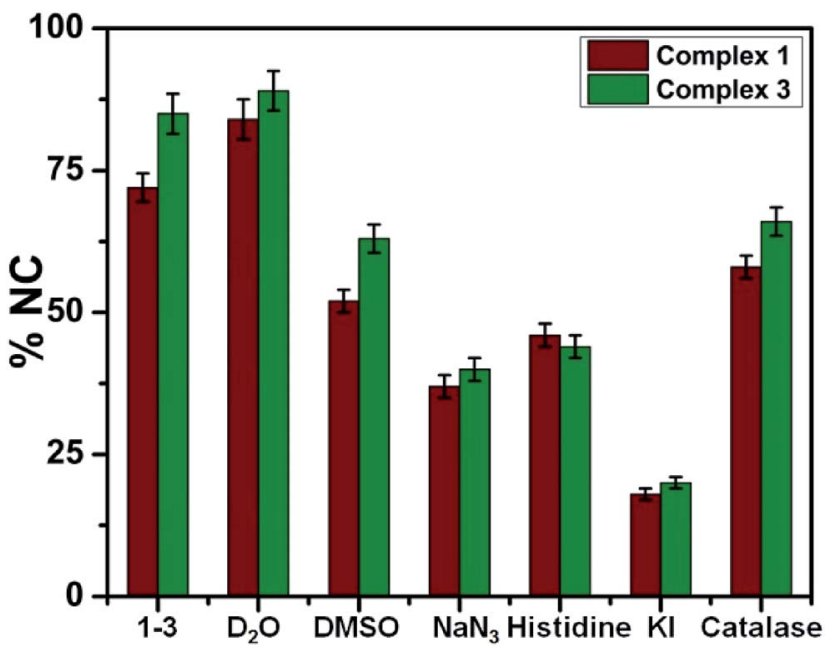

Fig. 7 Cleavage of SC pUC19 DNA (30 $\mu \mathrm{M}, 0.2 \mu \mathrm{g})$ by complexes 1 and $3(40 \mu \mathrm{M})$ (wine) and (olive) on photo-exposure at $365 \mathrm{~nm}(6 \mathrm{~W})$ for $1.5 \mathrm{~h}$ in the presence of various additives in Tris $-\mathrm{HCl} / \mathrm{NaCl}$ buffer. $\mathrm{NaN}_{3}, 0.4 \mathrm{mM}$; KI, $0.4 \mathrm{mM}$; $\mathrm{D}_{2} \mathrm{O}, 16 \mu \mathrm{L}$; L-histidine, $0.4 \mathrm{mM}$; DMSO, $4 \mu \mathrm{L}$; catalase, $4 \mathrm{U}$.

hydroxyl radical scavengers showed partial inhibition of photocleavage, suggesting the generation of ${ }^{\circ} \mathrm{OH}$ during the process. All the data shown in Fig. 7 and S22-S26 in ESI $\dagger$ confirms that photoinduced DNA cleavage here involves both Type-II and photoredox pathways and is consistent with earlier reported lanthanide complexes. ${ }^{23,24}$

\section{Conclusions}

Four new Eu(III) and Tb(III) complexes containing chalcones as biologically diverse molecules and TTA as ancillary sensitizing ligands have been designed, synthesized and characterized. The structurally characterized complex 3 showing an eight coordinated square antiprismatic $\left\{\mathrm{EuN}_{1} \mathrm{O}_{7}\right\}$ geometry. Strong luminescence from all the complexes suggest effective energy transfer from sensitizing ligands to $\mathrm{Ln}(\mathrm{III})$. Horrock's experiment showed the absence of any inner sphere $\mathrm{H}_{2} \mathrm{O}$ molecule $(q<$ 1) attached to $\mathrm{Ln}(\mathrm{III})$ in solution. Complexes showed good binding affinity with DNA and HSA as evidenced form spectroscopic studies. Both the chalcone ligands containing pyrene or anthracene acts as efficient photosensitizers to generate ROS for DNA photocleavage. These complexes showed effective photoinduced DNA cleavage under UV-A light of $365 \mathrm{~nm}$ at $40 \mu \mathrm{M}$ concentration through the generation of singlet oxygen $\left({ }^{1} \mathrm{O}_{2}\right)$ in a type-II pathway and ${ }^{\circ} \mathrm{OH}$ in a photoredox pathway. Further chalcone modifications with a series of antenna moieties for the development of highly emissive lanthanide chalcones complexes are in progress to study their various biological potential utilizing lanthanide luminescence.

\section{Experimental section}

\section{Materials}

Chemicals like 9-anthraldehyde, pyrene-1-carbaldehyde and 2acetyl pyridine were purchased from Alfa-Aesar. Theonyl trifluoro acetylacetone, europium chloride hexahydrate and terbium chloride hexahydrate were form Sigma Aldrich and used without any further purification. Solvents purchased from commercial sources were either of spectroscopic grade or purified by standard literature procedures. ${ }^{54} \operatorname{Ln}(\mathrm{TTA})_{3} \cdot 2 \mathrm{H}_{2} \mathrm{O}$ were prepared according to the literature reported procedure. ${ }^{55}$ Calf thymus (CT)-DNA, albumin from human serum (HSA), agarose (molecular biology grade), methyl green, catalase, gel loading solution and ethidium bromide were procured from Sigma (U.S.A.). Milli-Q water (18.2 M $\Omega$ ) was used to prepare Tris-(hydroxymethyl)-aminomethane-HCl (Tris-HCl) buffer solution. Supercoiled (SC) pUC19 DNA was from Merck Millipore (India).

\section{General measurements}

Perkin-Elmer Model 1320 FT-IR spectrometer was used for the infrared spectra with $\mathrm{KBr}$ disc in the operating range of 4000$400 \mathrm{~cm}^{-1}$. WATERS Q-TOF Premier mass spectrometer was used for recording electrospray ionization mass spectral (ESI-MS) measurements. ${ }^{1} \mathrm{H}$ NMR spectra were recorded using JEOLECX $500 \mathrm{FT}(400 \mathrm{MHz})$ for the characterization of chalcones at $298 \mathrm{~K}$ with reference to TMS. UV-Vis spectra were recorded using Varian V670 spectrophotometer at $298 \mathrm{~K}$.

Agilent Cary Eclipse fluorescence spectrophotometer was used for fluorescence and time resolved luminescence spectra measurements. Luminescence decay measurements were done with same instrument using a pulsed Xe-source at $\lambda_{\mathrm{ex}}=340 \mathrm{~nm}$ and emission at $616 \mathrm{~nm}$ for $\mathrm{Eu}(\mathrm{III})$ and $545 \mathrm{~nm}$ for $\mathrm{Tb}$ (III) complexes respectively. The decay curves were fitted using nonlinear least square method. Calculation for determination of number of $\mathrm{H}_{2} \mathrm{O}$ molecules coordinated to metal in the complexes 1-4 was done by the measurement of excited state lifetimes in $\mathrm{H}_{2} \mathrm{O}$ and $\mathrm{D}_{2} \mathrm{O}$ and thereby applying modified Horrocks equations for ternary europium and terbium complexes respectively. ${ }^{39}$

$$
\begin{aligned}
& q_{\mathrm{Eu}}=1.2\left(\frac{1}{\tau_{\mathrm{H}_{2} O}}-\frac{1}{\tau_{D_{2} O}}-0.25\right) \\
& q_{\mathrm{Tb}}=5.0\left(\frac{1}{\tau_{\mathrm{H}_{2} O}}-\frac{1}{\tau_{D_{2} O}}-0.06\right)
\end{aligned}
$$

\section{Synthesis and characterization}

Synthesis of chalcones. To a mixture of acetyl pyridine (0.60 g, $5 \mathrm{mmol}$ ) and 2-anthraldehyde (1.03 g, $5 \mathrm{mmol}$ ) or 1-pyrene carbaldehyde $(1.15 \mathrm{~g}, 5 \mathrm{mmol})$ was added an aqueous solution of $15 \% \mathrm{KOH}(5 \mathrm{~mL}, 1.5 \mathrm{M})$. The reaction mixture was stirred at RT for $24 \mathrm{~h}$ resulting in a yellow orange precipitate. The precipitate was filtered, washed with cold ethanol $(3 \times$ $5 \mathrm{~mL}$ ) and dried in vacuum over $\mathrm{P}_{2} \mathrm{O}_{5}$. Precipitate obtained was further recrystallized from ethanol to give the final product (Scheme 2). ${ }^{34,35}$ The characterization data are given below:

(E)-3-(Anthracen-9-yl)-1-(pyridin-2-yl)prop-2-en-1-one (Anpp). Yield: $1.24 \mathrm{~g}$ (78\%), UV-Vis (DMF): $\lambda_{\max }\left(\varepsilon / \mathrm{L} \mathrm{mol}^{-1} \mathrm{~cm}^{-1}\right)=267$ 
(93 800), 333 (10 800), 351 (19 600), 368 (27 000), 388 (26 900). FT-IR (in $\mathrm{KBr} / \mathrm{cm}^{-1}$ ): 3051 (br, aromatic $\mathrm{C}-\mathrm{H}$ ), $1670(\mathrm{~s}, \mathrm{C}=\mathrm{O}$ ), 1599 (s), 1582 (s), 1565 (s). ${ }^{1} \mathrm{H}$ NMR (400 MHz, $\mathrm{CDCl}_{3}, \delta$ from TMS): 8.9 (d, 1H), 8.68 (1H, d), $8.48(1 \mathrm{H}, \mathrm{s}), 8.34(2 \mathrm{H}, \mathrm{m}), 8.29$ (1H, d; 1H, s), $8.03(2 \mathrm{H}, \mathrm{m}), 7.93(2 \mathrm{H}, \mathrm{td}), 7.5(4 \mathrm{H}, \mathrm{m})$. ESI-MS $(m / z):[\mathrm{M}+\mathrm{H}]^{+}$calcd for $\mathrm{C}_{22} \mathrm{H}_{16} \mathrm{~N}_{1} \mathrm{O}_{1}, 310.123$; found, 310.125 .

(E)-3-(Pyren-1-yl)-1-(pyridin-2-yl)prop-2-en-1-one (Pypp). Yield: $1.14 \mathrm{~g}(73 \%)$, UV-Vis (DMF): $\lambda_{\max }\left(\varepsilon / \mathrm{L} \mathrm{mol} \mathrm{mol}^{-1} \mathrm{~cm}^{-1}\right)=270$ (91 000), 310 (59 600), 344 (45 300), 390 (70 300), 422 (69 800). FT-IR (in $\mathrm{KBr} / \mathrm{cm}^{-1}$ ): 3044 (br, aromatic C-H), 1660 (s, C=O), 1588 (s), 1574 (s), 1560 (m). ${ }^{1} \mathrm{H}$ NMR: (400 MHz, $\mathrm{CDCl}_{3}, \delta$ from TMS): 9.10 (1H, d), 8.78 (1H, s), $8.56(3 \mathrm{H}, \mathrm{m}), 8.18(5 \mathrm{H}, \mathrm{m}), 8.02$ $(2 \mathrm{H}, \mathrm{m}), 7.90(1 \mathrm{H}, \mathrm{s}), 8.69(1 \mathrm{H}, \mathrm{d}), 7.51(1 \mathrm{H}, \mathrm{s})$. ESI-MS $(\mathrm{m} / \mathrm{z}):[\mathrm{M}+$ $\mathrm{H}]^{+}$calcd for $\mathrm{C}_{24} \mathrm{H}_{16} \mathrm{~N}_{1} \mathrm{O}_{1}, 334.123$; found, 334.124.

Synthesis of lanthanide complexes. To a solution of respective $\mathrm{Ln}(\mathrm{TTA})_{3} \cdot 2 \mathrm{H}_{2} \mathrm{O}(85.10 \mathrm{mg}$ for $\mathrm{Eu}$ and $85.80 \mathrm{mg}$ for $\mathrm{Tb}, 0.1$ $\mathrm{mmol}$ ) in THF (5 mL) was added a solution of chalcones (37.21 $\mathrm{mg}$ for Anpp and $39.96 \mathrm{mg}$ for Pypp, $0.12 \mathrm{mmol}$ ) and left on stirring for $12 \mathrm{~h}$. The resulting solution was dried in vacuum and then redissolved in a minimum amount of THF. To this solution an excess of hexane was added to precipitate out the final product. The precipitate was filtered, washed with $5 \mathrm{~mL}$ diethyl ether and dried to give the desired product [ $\operatorname{Ln}(\mathrm{Anpp}) /$ (Pypp)(TTA) $)_{3}$ (1-4) in a good yield (Scheme 2).

[Eu(Anpp)(TTA $\left.)_{3}\right]$ (1). Yield: $73.06 \mathrm{mg}(65 \%)$. UV-Vis (DMF): $\lambda_{\max }\left(\varepsilon / \mathrm{L} \mathrm{mol}^{-1} \mathrm{~cm}^{-1}\right)=270$ (69 400), 346 (49 500). FT-IR (in $\left.\mathrm{KBr} / \mathrm{cm}^{-1}\right): \nu=3432\left(\mathrm{w}, \mathrm{br}, \nu_{\mathrm{O}-\mathrm{H}}\right), 3053(\mathrm{w}), 2925(\mathrm{w}), 1601$ $\left(\mathrm{s}, \nu_{\mathrm{C}=\mathrm{O}}\right), 1537$ (s), 1504 (m), 1464 (m), 1411 (s), 1356 (s), 1305 (s), 1247 (m), 1229 (s), 1186 (s), 1139 (s), 1059 (m), 933 (s), 892 $(\mathrm{m}), 858(\mathrm{~m}), 786\left(\mathrm{~s}, \nu_{\mathrm{CF} 3}\right), 767(\mathrm{~s}), 735(\mathrm{~s}), 720(\mathrm{~s}), 680(\mathrm{~m}), 619$ $(\mathrm{s}), 580(\mathrm{~s}), 519\left(\mathrm{w}, \nu_{\mathrm{Eu}-\mathrm{N}}\right), 491\left(\mathrm{w}, \nu_{\mathrm{Eu}-\mathrm{O}}\right) . \operatorname{ESI}-\mathrm{MS}(\mathrm{m} / \mathrm{z}):$ [M-TTA $^{+}$ calcd for $\mathrm{C}_{38} \mathrm{H}_{23} \mathrm{~N}_{1} \mathrm{O}_{5} \mathrm{~F}_{6} \mathrm{~S}_{2} \mathrm{Eu}_{1}$, 904.013; found, 904.011.

[Tb(Anpp)(TTA) 3 (2). Yield: $75.80 \mathrm{mg}(67 \%)$. UV-Vis (DMF): $\lambda_{\max }\left(\varepsilon / \mathrm{L} \mathrm{mol}^{-1} \mathrm{~cm}^{-1}\right)=271$ (69 000), 346 (42 700). FT-IR (in $\left.\mathrm{KBr} / \mathrm{cm}^{-1}\right): \nu=3425\left(\mathrm{w}, \mathrm{br}, \nu_{\mathrm{O}-\mathrm{H}}\right), 3084(\mathrm{w}), 2963(\mathrm{~s}), 1603\left(\mathrm{~s}, \nu_{\mathrm{C}}=\right.$ o), 1537 (s), 1502 (m), 1460 (m), 1412 (s), 1354 (s), 1305 (s), 1261 (s), 1229 (s), 1183 (s), 1098 (s), 1059 (s), 1020 (s), 932 (s), 877 (m), $858(\mathrm{~m}), 799$ (s, $\left.\nu_{\mathrm{CF} 3}\right), 735(\mathrm{~s}), 717$ (s), 679 (s), 640 (s), 579 (s), 519 (w, $\left.\nu_{\mathrm{Tb}-\mathrm{N}}\right), 486\left(\mathrm{w}, \nu_{\mathrm{Tb}-\mathrm{O}}\right)$. ESI-MS $(\mathrm{m} / \mathrm{z})$ : $[\mathrm{M}-\mathrm{TTA}]^{+}$calcd for $\mathrm{C}_{38^{-}}$ $\mathrm{H}_{23} \mathrm{~N}_{1} \mathrm{O}_{5} \mathrm{~F}_{6} \mathrm{~S}_{2} \mathrm{~Tb}_{1}, 910.0175$; found, 910.0154 .

[Eu(Pypp)(TTA $\left.)_{3}\right]$ (3). Yield: $68.90 \mathrm{mg}(60 \%) . \mathrm{UV}-\mathrm{Vis}(\mathrm{DMF}): \lambda_{\max }$ $\left(\varepsilon / \mathrm{L} \mathrm{mol}^{-1} \mathrm{~cm}^{-1}\right)=273$ (88 200), 344 (77 700), 440 (36 600). FT-IR (in $\mathrm{KBr} / \mathrm{cm}^{-1}$ ): $\nu=3432\left(\mathrm{w}, \mathrm{br}, \nu_{\mathrm{O}-\mathrm{H}}\right), 3091(\mathrm{w}), 2962(\mathrm{~s}), 2925(\mathrm{w})$, 1602 (vs., $\nu_{\mathrm{C}=\mathrm{O}}$ ), 1536 (s), 1505 (m), 1459 (m), 1411 (s), 1353 (s), 1305 (s), 1261 (s), 1229 (s), 1185 (s), 1133 (s), 1092 (s) 1060 (m), 1025 (s),

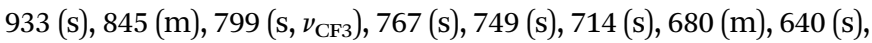
580 (s), 519 (w, $\left.\nu_{\mathrm{Eu}-\mathrm{N}}\right), 491 \mathrm{~cm}^{-1}$ (w, $\left.\nu_{\mathrm{Eu}-\mathrm{O}}\right)$. ESI-MS $(\mathrm{m} / \mathrm{z}):[\mathrm{M}+\mathrm{Na}]^{+}$ calcd for $\mathrm{C}_{48} \mathrm{H}_{27} \mathrm{~N}_{1} \mathrm{O}_{7} \mathrm{~F}_{9} \mathrm{~S}_{3} \mathrm{Eu}_{1} \mathrm{Na}_{1}$, 1171.991; found, 1171.970.

[Tb(Pурр)(TTA $\left.)_{3}\right]$ (4). Yield: $72.80 \mathrm{mg}(63 \%)$. UV-Vis (DMF): $\lambda_{\max }\left(\varepsilon / \mathrm{L} \mathrm{mol}^{-1} \mathrm{~cm}^{-1}\right)=273$ (86 800), 344 (72 800), 440 (31 200). FT-IR (in KBr/cm ${ }^{-1}$ ): $\nu=3433$ (w, br, $\nu_{\mathrm{O}-\mathrm{H}}$ ), 3046 (w), 2963 (s), $2925(\mathrm{w}), 1602$ (s, $\left.\nu_{\mathrm{C}=\mathrm{O}}\right), 1535$ (s), $1504(\mathrm{~m}), 1464(\mathrm{~m}), 1411$ (s), 1353 (s), 1304 (s), 1261 (s), 1229 (s), 1184 (s), 1099 (s), 1061 (s), 1023 (s), 932 (s), $844(\mathrm{~m}), 799$ (s, $\left.\nu_{\mathrm{CF} 3}\right), 767$ (s), 735 (s), 713 (s), 679 (m), 640 (s), 614 (s), 579 (s), 519 (w, $\left.\nu_{\mathrm{Tb}-\mathrm{N}}\right), 491$ (w, $\left.\nu_{\mathrm{Tb}-\mathrm{O}}\right)$. ESI-MS $(\mathrm{m} / \mathrm{z})$ : [M-TTA $]^{+}$calcd for $\mathrm{C}_{38} \mathrm{H}_{23} \mathrm{~N}_{1} \mathrm{O}_{5} \mathrm{~F}_{6} \mathrm{~S}_{2} \mathrm{~Tb}_{1}, 934.0175$; found, 934.0212.

\section{Single crystal X-ray crystallography}

$\left[\mathrm{Eu}(\mathrm{Pypp})(\mathrm{TTA})_{3}\right]$ (3) was structurally characterized by single crystal X-ray diffraction technique. A crystal of proper size was mounted on a glass fiber and used for collecting the data. X-ray diffraction data were collected using $\omega$-scan technique (width of $0.5^{\circ}$ per frame) at a scan rate of $10 \mathrm{~s}$ each frame on a Bruker D8 Quest microfocus X-ray CCD diffractometer with graphite monochromated Mo $\mathrm{K}_{\alpha}$ radiation $(\lambda=0.71073 \AA)$ at $100(2) \mathrm{K}$ controlled by an APEX2 v2012.4-3 software. ${ }^{56}$ Data were corrected for Lorentz polarization correction thereafter processed with Bruker's SAINT software which was collected using $\omega-2 \theta$ scan mode. ${ }^{57}$ Absorption corrections were applied on a SADABS program to the collected reflections and space group was determined from XPREP. ${ }^{58}$ The structure solved on a SHELXL97 by direct methods, were refined using SHELXTL-6.14 program on a $F^{2}$ full-matrix least square method. Subsequently obtained structure was refined on a SHEXTL-97 associated to WinGX-1.70 crystallographic package. ${ }^{59-61} \mathrm{C} 38$ atom in one TTA ligand having site occupancy factor (SOF) of 0.5 in the asymmetric unit. A perspective view of the complex was obtained using ORTEP (Fig. 2) after including all the hydrogen atoms in geometrically calculated positions refined with riding hydrogen model and all other non-hydrogen atoms were anisotropically refined. ${ }^{62}$ Selected bond length and bond angles are shown in Table S1. $\dagger$ CCDC deposition number: CCDC 1566126. Crystallographic data for 3: $\mathrm{C}_{47.5} \mathrm{H}_{26.5} \mathrm{Eu}_{1} \mathrm{~F}_{9} \mathrm{~N}_{1} \mathrm{O}_{7} \mathrm{~S}_{3}, M=1142.34$, triclinic, space group $P \overline{1}, a=10.5489(9), b=10.8247(9), c=$ 21.7672(19) ̊, $\alpha=99.053(2), \beta=101.429(2), \gamma=105.634(2)^{\circ}, V=$ 2286.9(3) $\AA^{3}, Z=2, D_{x}\left(\mathrm{~g} \mathrm{~cm}^{-3}\right)=1.659, T=100(2) \mathrm{K}, \theta$ range $=$ $2.00-25.07^{\circ}, \mu=1.598 \mathrm{~mm}^{-1}, F(000)=1133$, reflections collected $=45431$, unique reflections $=8100\left(R_{\text {int }}=0.0588\right) T_{\max } / T_{\min },=$ $0.7619 / 0.7406$, data/restraints/parameters $=8100 / 2 / 604$, GOF on $F^{2}=1.109, R_{1}$ and $\mathrm{w} R_{2}[I>2 \sigma(I)]=0.0663,0.1726 ; 45431$ collected reflections, 8100 unique reflections, $R_{\mathrm{int}}=0.0588$, final $R_{1}=0.0806$ and $\mathrm{w} R_{2}=0.1867$ (all data).

\section{DNA binding experiments}

Electronic absorption spectral studies. DNA binding studies were done by absorption spectral titration experiment in $5 \mathrm{mM}$ Tris HCl-5 mM NaCl buffer (pH-7.2) using DMF solution of the complexes 1-4. An absorbance ratio $\left(A_{260} / A_{280}\right)$ of $1.8-1.9$ of calf thymus DNA found in Tris HCl-NaCl buffer showing that there is hardly any scares of protein in DNA solution. ${ }^{63}$ The known molar extinction coefficient $\left(\varepsilon_{260}=6600 \mathrm{M}^{-1} \mathrm{~cm}^{-1}\right)$ and the absorbance recorded at $260 \mathrm{~nm}\left(A_{260}\right)$ gave the concentration of DNA. ${ }^{64}$ UV-Vis absorption spectral titrations were done by varying DNA concentration while keeping the fixed complex concentration. The following eqn (1) was used to determine intrinsic binding constant $\left(K_{\mathrm{b}}\right)$ with ternary lanthanide complexes.

$$
[\mathrm{DNA}] /\left(\varepsilon_{\mathrm{a}}-\varepsilon_{\mathrm{f}}\right)=[\mathrm{DNA}] /\left(\varepsilon_{\mathrm{b}}-\varepsilon_{\mathrm{f}}\right)+1 / K_{\mathrm{b}}\left(\varepsilon_{\mathrm{b}}-\varepsilon_{\mathrm{f}}\right)
$$

where [DNA] is the concentration of DNA in base pairs and $\varepsilon_{\mathrm{a}}$ is apparent molar absorptivity of the complexes while $\varepsilon_{\mathrm{f}}$ and $\varepsilon_{\mathrm{b}}$ are the molar absorptivity of the complexes in their free form and 
when completely bound to DNA. ${ }^{65}$ The DNA binding constant was obtained from slope to intercept ratio of the $[\mathrm{DNA}] /\left[\varepsilon_{\mathrm{a}}-\varepsilon_{\mathrm{f}}\right]$ vs. [DNA] plot.

Competitive binding assay. Ethidium bromide (EB) displacement assay used for estimation of competitive binding with DNA and complexes were studied in Tris $\mathrm{HCl}-\mathrm{NaCl}$ buffer by recording the variation in the emission intensity of EB bound to DNA at $603 \mathrm{~nm}\left(\lambda_{\mathrm{exc}}=546 \mathrm{~nm}\right)$. In comparison to the EB-DNA adduct, the emission intensity of free form of EB is very less because of its quenching from the solvent molecule in buffer medium. The enhanced emission intensity of DNA bound EB was quenched upon addition of the complexes 1-4 and recorded at increasing concentration of the complexes. The apparent binding constants of the complexes were calculated using the following equation:

$$
K_{\text {app }} \times C_{50}=K_{\mathrm{EB}} \times[\mathrm{EB}]
$$

where $K_{\text {app }}$ stands for apparent binding constant of the complexes studied, $C_{50}$ is the concentration of the complexes added at which emission intensity reduces to 50\% from EBDNA adduct, $K_{\mathrm{EB}}$ is the binding constant of ethidium bromide $\left(K_{\mathrm{EB}}=1 \times 10^{7} \mathrm{M}^{-1}\right)$ and [EB] is the concentration of the ethidium bromide in buffer medium $(12 \mu \mathrm{M}){ }^{66}$

Protein binding experiments. Protein binding interaction studies of the complexes 1-4 were carried out in $5 \mathrm{mM}$ Tris $\mathrm{HCl}-$ $5 \mathrm{mM} \mathrm{NaCl}$ buffer (pH-7.2) using human serum albumin (HSA). A stock solution of HSA was prepared in Tris buffer and its concentration was calculated from known molar absorptivity $\left(\varepsilon_{278}=44000 \mathrm{dm}^{3} \mathrm{~mol}^{-1} \mathrm{~cm}^{-1}\right)$ and the recorded absorbance $\left(A_{278}\right)$ at $278 \mathrm{~nm} .{ }^{67,68}$ After taking a $1 \mu \mathrm{M}$ solution of HSA, a quenching in emission intensity at $345 \mathrm{~nm}\left(\lambda_{\text {exc }}=295 \mathrm{~nm}\right)$ of the tryptophan residue present in protein was recorded upon increasing concentration of the complexes. The quenching constants were calculated using Stern-Volmer equation: ${ }^{46}$

$$
I_{0} / I=1+K_{\mathrm{HSA}}[\mathrm{Q}]
$$

where, $I_{0}$ and $I$ are the emission intensities of HSA in the absence of a quencher and in the presence of a quencher of concentration [Q], gave the quenching constants $\left(K_{\mathrm{HSA}}\right)$. Slope of the plot $I_{0} / I v s$. [Q] gave the value of $K_{\mathrm{HSA}}$.

The values of binding constant $(K)$ and number of binding sites $(n)$ was obtained from the linear $\log \left(I_{0} / I-1\right) v s . \log [\mathrm{Q}]$ plot using Scatchard equation: ${ }^{47}$

$$
\log \left[\left(I_{0}-I\right) / I\right]=\log K+n \log [\mathrm{Q}]
$$

Synchronous fluorescence spectroscopy. Synchronous emission spectra were recorded to get insight into the binding preference of the complexes 1-4 in different microenvironment of serum protein. This experiment was carried out by taking $1 \mu \mathrm{M}$ concentration of HSA in Tris $\mathrm{HCl}-\mathrm{NaCl}$ buffer with the addition of complex at $\Delta \lambda=15 \mathrm{~nm}$ corresponding to the tyrosine residue and $\Delta \lambda=60 \mathrm{~nm}$ corresponding to tryptophan residue of the serum protein.
DNA photocleavage experiment. The cleavage of supercoiled (SC) pUC19 DNA (30 $\mu \mathrm{M}, 0.2 \mu \mathrm{g}, 2686$ base pairs) was done with photoinduced reactions by agarose gel electrophoresis in Tris acetate-EDTA (TAE) buffer ( $\mathrm{pH}$ 8.1) at various concentration of the complexes 1-4. The concentration of complexes 1-4 in DMF or any other additive in buffer were reported only after their dilution to a final volume of $20 \mu \mathrm{L}$ by $50 \mathrm{mM}$ Tris $\mathrm{HCl}$ buffer. After an incubation for $1 \mathrm{~h}$ at $37{ }^{\circ} \mathrm{C}$, photoirradiation of the sample were carried out in dark using UV-A light of $365 \mathrm{~nm}$ ( 6 W, Model VL-6.LC from Vilber Lourmat, France). Mechanistic study was carried out by taking various additives viz. DMSO, $\mathrm{NaN}_{3}$, L-histidine, KI, catalase, $\mathrm{D}_{2} \mathrm{O}$ to DNA solution prior to addition of complexes. For studying effect of $\mathrm{D}_{2} \mathrm{O}, \mathrm{D}_{2} \mathrm{O}$ itself was taken for the dilution of sample upto $20 \mu \mathrm{L}$. After photoirradiation of sample, a $3 \mu \mathrm{L}$ of loading buffer consist of $0.25 \%$ bromophenol, $0.25 \%$ xylene cyanol, $40 \%$ sucrose was mixed to it. Finally, the sample solution was loaded on a $1 \%$ agarose gel containing $1 \mu \mathrm{g} \mathrm{mL}{ }^{-1}$ ethidium bromide and electrophoresis of the sample was carried out in TAE buffer (pH-8.1) at $60 \mathrm{~V}$ for $2 \mathrm{~h}$ in dark. UV-A light was used for visualization and images taken with UVITEC FireReader V4 gel documentation system. The cleavage products were quantified by measuring the intensity of the band on a UVI band software. The error observed was in the range of $4-6 \%$ in measuring the band intensities.

\section{Conflicts of interest}

There are no conflicts to declare.

\section{Acknowledgements}

We thank IIT Kanpur for infrastructure and the Science and Engineering Research Board (SERB) for financial support (EMR/ 2016/000521). ZA thanks to University Grants Commission (UGC) and SD to Ministry of Human Resources and Development (MHRD) for the research fellowships.

\section{Notes and references}

1 S. Cotton, Lanthanides and actinide chemistry, John Wiley \& Sons Ltd., England, 2006.

2 (a) M. C. Hefferin, L. M. Matosziuk and T. J. Meade, Chem. Rev., 2014, 114, 4496-4539; (b) J. L. Major and T. J. Meade, Acc. Chem. Res., 2009, 42, 893-903; (c) S. Shuvaev, M. Starck and D. Parker, Chem.-Eur. J., 2017, 23, 9974-9989.

3 (a) P. Caravan, J. J. Ellison, T. J. McMurry and R. B. Lauffer, Chem. Rev., 1999, 99, 2293-2352; (b) P. Caravan, Chem. Soc. Rev., 2006, 35, 512-523; (c) M. Mikawa, H. Kato, M. Okumura, M. Narazaki, Y. Kanazawa, N. Miwa and H. Shinohara, Bioconjugate Chem., 2001, 12, 510-514.

4 (a) J.-C. G. Bünzli, Chem. Rev., 2010, 110, 2729-2755; (b) S. V. Eliseeva and J.-C. G. Bünzli, Chem. Soc. Rev., 2010, 39, 189-227.

5 (a) E. G. Moore, A. P. S. Samuel and K. N. Raymond, Acc. Chem. Res., 2009, 42, 542-552; (b) A. J. Amoroso and S. J. A. Pope, Chem. Soc. Rev., 2015, 44, 4723-4742. 
6 (a) S. Gai, C. Li, P. Yang and J. Lin, Chem. Rev., 2014, 114, 2343-2389; (b) H. Terraschke and C. Wickleder, Chem. Rev., 2015, 115, 11352-11378.

7 (a) J.-C. G. Bünzli and C. Piguet, Chem. Soc. Rev., 2005, 34, 1048-1077; (b) H. Tsukube and S. Shinoda, Chem. Rev., 2002, 102, 2389-2403; (c) H. Tsukube and S. Shinoda, Analyst, 2011, 136, 431-435.

8 (a) L. V. Meyer, F. Schönfeld and K. M. Buschbaum, Chem. Commun., 2014, 50, 8093-8108; (b) J. Heine and K. M. Buschbaum, Chem. Soc. Rev., 2013, 42, 9232-9242; (c) J. Rocha, L. D. Carlos, F. A. A. Paz and D. Ananias, Chem. Soc. Rev., 2011, 40, 926-940.

9 (a) S. M. Larson, J. A. Carrasquillo, N.-K. V. Cheung and O. W. Press, Nat. Rev. Cancer, 2015, 15, 347-360; (b) R. D. Teo, J. Termini and H. B. Gray, J. Med. Chem., 2016, 59, 6012-6024.

10 (a) M. D. Gross, G. L. Nelsestuen and R. Kumar, J. Biol. Chem., 1987, 262, 6539-6545; (b) J. M. Harrowfield, M. I. Ogden, W. R. Richmond and A. H. Whit, J. Chem. Soc., Dalton Trans., 1991, 2153-2160.

11 (a) S. P. Fricker, Chem. Soc. Rev., 2006, 35, 524-533; (b) K. Wang, R. Li, Y. Cheng and B. Zhu, Coord. Chem. Rev., 1999, 190-192, 297-308.

12 (a) M. Bottrill, L. Kwok and N. J. Long, Chem. Soc. Rev., 2006, 35, 557-571; (b) P. Hermann, J. Kotek, V. KubÍček and I. Lukeš, Dalton Trans., 2008, 23, 3027-3047.

13 R. Bonnett, Chemical Aspects of Photodynamic Therapy, Gordon \& Breac, London, UK, 2000.

14 (a) D. E. J. G. J. Dolmans, D. Fukumura and R. K. Jain, Nat. Rev. Cancer, 2003, 23, 380-387; (b) J. L. Sessler and R. A. Miller, Biochem. Pharmacol., 2000, 59, 733-739; (c) G. Thiabaud, R. McCall, G. He, J. F. Arambula, Z. H. Siddik and J. L. Sessler, Angew. Chem., Int. Ed., 2016, 55, 1262612631.

15 (a) M. Ethirajan, Y. Chen, P. Joshi and R. K. Pandey, Chem. Soc. Rev., 2011, 40, 340-362; (b) M. R. Detty, S. L. Gibson and S. J. Wagner, J. Med. Chem., 2004, 47, 3897-3915; (c) M. Triesscheijn, P. Baas, J. H. M. Schellens and F. A. Stewart, Oncologist, 2006, 11, 1034-1044.

16 (a) J. P. Celli, B. Q. Spring, I. Rizvi, C. L. Evans, K. L. Samkoe, S. Verma, B. W. Pogue and T. Hasan, Chem. Rev., 2010, 110, 2795-2838; (b) K. Szaciłowski, W. Macyk, A. D. Matuszek, M. Brindell and M. Stochel, Chem. Rev., 2005, 105, 26472694.

17 (a) S. I. Moriwaki, J. Misawa, Y. Yoshinari, I. Yamada, M. Takigawa and Y. Tokura, Photodermatol., Photoimmunol. Photomed., 2001, 17, 241-243; (b) M. Ochsner, J. Photochem. Photobiol., B, 1996, 32, 3-9.

18 R. R. Allison and C. H. Sibata, Photodiagn. Photodyn. Ther., 2010, 7, 61-75.

19 (a) F. S. Mackay, J. A. Woods, P. Heringová, J. Kaspárková, A. M. Pizarro, S. A. Moggach, S. Parsons, V. Brabec and P. J. Sadler, Proc. Natl. Acad. Sci. U. S. A., 2007, 104, 2074320748; (b) N. J. Farrer, J. A. Woods, L. Salassa, Y. Zhao, K. S. Robinson, G. Clarkson, F. S. Mackay and P. J. Sadler, Angew. Chem., Int. Ed., 2010, 49, 8905-8908; (c) N. J. Farrer, L. Salassa and P. J. Sadler, Dalton Trans., 2009, 10690-10701.
20 (a) D. A. Lutterman, P. K.-L. Fu and C. Turro, J. Am. Chem. Soc., 2006, 128, 738-739; (b) A. M. Angeles-Boza, H. T. Chifotides, J. D. Aguirre, A. Chouai, P. K.-L. Fu, K. R. Dunbar and C. Turro, J. Med. Chem., 2006, 49, 68416847.

21 (a) K. Mitra, S. Gautam, P. Kondaiah and A. R. Chakravarty, Angew. Chem., Int. Ed., 2015, 54, 13989-13993; (b) W. Lu, D. A. Vicic and J. K. Barton, Inorg. Chem., 2005, 44, 7970-7980. 22 (a) S. Swavey and K. J. Brewer, Inorg. Chem., 2002, 41, 61966198; (b) A. A. Holder, S. Swavey and K. J. Brewer, Inorg. Chem., 2004, 43, 303-308.

23 (a) A. Hussain, D. Lahiri, M. S. A. Begum, S. Saha, R. Majumdar, R. R. Dighe and A. R. Chakravarty, Inorg. Chem., 2010, 49, 4036-4045; (b) A. Hussain, S. Gadadhar, T. K. Goswami, A. A. Karande and A. R. Chakravarty, Eur. J. Med. Chem., 2012, 50, 319-331; (c) A. Hussain, K. Somyajit, B. Banik, S. Banerjee, G. Nagaraju and A. R. Chakravarty, Dalton Trans., 2013, 42, 182-195.

24 (a) S. Dasari and A. K. Patra, Dalton Trans., 2015, 44, 1984419855; (b) S. Dasari, S. Singh, S. Sivakumar and A. K. Patra, Chem.-Eur. J., 2016, 22, 17387-17396; (c) A. Chandra, K. Singh, S. Singh, S. Sivakumar and A. K. Patra, Dalton Trans., 2016, 45, 494-497; (d) K. Singh, S. Singh, P. Srivastava, S. Sivakumar and A. K. Patra, Chem. Commun., 2017, 53, 6144-6147.

25 M. Sy, A. Nonat, N. Hildebrandt and L. J. Charbonnihre, Chem. Commun., 2016, 52, 5080-5095.

26 (a) V. Divya, M. L. P. Reddy and R. Pavithran, Dalton Trans., 2013, 42, 15249-15262; (b) D. B. A. Raj, S. Biju and M. L. P. Reddy, Inorg. Chem., 2008, 47, 8091-8100; (c) P. Martín-Ramos, C. Coya, Á. L. Álvarez, M. R. Silva, C. Zaldo, J. A. Paixao, P. Chamorro-Posada and J. MartínGil, J. Phys. Chem. C, 2013, 117, 10020-10030; (d) J. Shi, Y. Hou, W. Chu, X. Shi, H. Gu, B. Wang and Z. Sun, Inorg. Chem., 2013, 52, 5013-5022.

27 (a) J. Yu, L. Zhou, H. Zhang, Y. Zheng, H. Li, R. Deng, Z. Peng and Z. Li, Inorg. Chem., 2005, 44, 1611-1618; (b) Y. Zheng, J. Lin, Y. Liang, Q. Lin, Y. Yu, Q. Meng, Y. Zhou, S. Wang, H. Wang and H. Zhang, J. Mater. Chem., 2001, 11, 2615-2619. 28 C. Zhuang, W. Zhang, C. Sheng, W. Zhang, C. Xing and Z. Miao, Chem. Rev., 2017, 117, 7762-7810.

29 (a) J. Li, D. Li, Y. Xu, Z. Guo, X. Liu, H. Yang, L. Wu and L. Wang, Bioorg. Med. Chem. Lett., 2017, 27, 602-606; (b) Z. Liu, L. Tang, P. Zou, Y. Zhang, Z. Wang, Q. Fang, L. Jiang, G. Chen, Z. Xu, H. Zhang and G. Liang, Eur. J. Med. Chem., 2014, 74, 671-682.

30 (a) N. J. Lawrence, R. P. Patterson, L.-L. Ooi, D. Cook and S. Ducki, Bioorg. Med. Chem. Lett., 2006, 16, 5844-5848; (b) N. Mateeva, S. V. K. Eyunni, K. K. Redda, U. Ononuju, T. D. Hansberry, C. Aikens and A. Nag, Bioorg. Med. Chem. Lett., 2017, 27, 2350-2356.

31 (a) M. Liu, P. Wilairat and M. L. Go, J. Med. Chem., 2001, 44, 4443-4452; (b) J. N. Dominguez, C. Leon, J. Rodrigues, N. Gamboa de Dominguez, J. Gut and P. J. Rosenthal, J. Med. Chem., 2005, 48, 3654-3658.

32 P. M. Sivakumar, T. M. Kumar and M. Doble, Chem. Biol. Drug Des., 2009, 74, 68-79. 
33 (a) S. Shettigar, K. Chandrasekharan, G. Umesh, B. K. Sarojini and B. Narayana, Polymer, 2006, 47, 35653567; (b) Y. J. Jung, K.-I. Son, Y. E. Oh and D.-Y. Noh, Polyhedron, 2008, 27, 861-867.

34 (a) P. M. Gallego, H. D. Dulk, J. Brouwer, H. Kooijman, A. L. Spek, O. Roubeau, S. J. Teat and J. Reedijk, Inorg. Chem., 2008, 47, 11171-11179; (b) B. Song, G. Wang, M. Tan and J. Yuan, J. Am. Chem. Soc., 2006, 128, 1344213450

35 (a) M. Chhatwal, A. Kumar, R. D. Gupta and S. K. Awasthi, RSC Adv., 2015, 5, 51678-51681; (b) K. C. Rout and B. Mondal, Inorg. Chim. Acta, 2015, 437, 54-58.

36 (a) J. Yu, L. Zhou, H. Zhang, Y. Zheng, H. Li, R. Deng, Z. Peng and Z. Li, Inorg. Chem., 2005, 44, 1611-1618; (b) J. Li, H. Li, P. Yan, P. Chen, G. Hou and G. Li, Inorg. Chem., 2012, 51, 5050-5057; (c) J. Sun, B. Song, Z. Ye and J. Yuan, Inorg. Chem., 2015, 54, 11660-11668; (d) J. Shi, Y. Hou, W. Chu, X. Shi, H. Gu, B. Wang and Z. Sun, Inorg. Chem., 2013, 52, 5013-5022.

37 P. Martín-Ramos, C. Coya, Á. L. Álvarez, M. R. Silva, C. Zaldo, J. A. Paixão, P. Chamorro-Posada and J. Martín-Gil, J. Phys. Chem. C, 2013, 117, 10020-10030.

38 (a) P. Lenaerts, K. Driesen, R. V. Deun and K. Binnemans, Chem. Mater., 2005, 17, 2148-2154; (b) P. Lenaerts, E. Ryckebosch, K. Driesen, R. V. Deun, P. Nockemann, C. G. Walrand and K. Binnemans, J. Lumin., 2005, 114, 7784; (c) R.-J. Zhang, K.-Z. Yang, A.-C. Yub and X.-S. Zhao, Thin Solid Films, 2000, 363, 275-278.

39 (a) W. D. Horrocks Jr and D. R. Sudnick, J. Am. Chem. Soc., 1979, 101, 334-340; (b) A. Beeby, I. M. Clarkson, R. S. Dickins, S. Faulkner, D. Parker, L. Royle, A. S. de Sousa, J. A. G. Williams and M. Woods, J. Chem. Soc., Perkin Trans. 1, 1999, 493-504.

40 (a) E. C. Long and J. K. Barton, Acc. Chem. Res., 1990, 23, 271273; (b) A. C. Komor and J. K. Barton, Chem. Commun., 2013, 49, 3617-3630.

41 (a) T. M. Kelly, A. B. Tossi, D. J. McConnell and T. C. Strekas, Nucleic Acids Res., 1985, 13, 6017-6034; (b) V. A. Bloomfield, D. M. Crothers and I. Tinocoo Jr, Physical Chemistry of Nucleic Acids, Harper \& Row, New York, 1974, p. 432; (c) J. B. Chaires, Curr. Opin. Struct. Biol., 1998, 8, 314-320.

42 (a) J. Olmsted III and D. R. Kearns, Biochemistry, 1977, 16, 3647-3754; (b) D. L. Boger, B. E. Fink, S. R. Brunnette, W. C. Tse and M. P. Hedrick, J. Am. Chem. Soc., 2001, 123, 5878-5891.

43 (a) M. J. Waring, J. Mol. Biol., 1965, 13, 269-282; (b) B. C. Baguley and E.-M. Falkenhaug, Nucleic Acids Res., 1978, 5, 161-171.

44 (a) S. Curry, H. Mandelkow, P. Brick and N. Franks, Nat. Struct. Biol., 1998, 5, 827-835; (b) J. Ghuman, P. A. Zunszain, I. Petitpas, A. A. Bhattacharya, M. Otagiri and S. Curry, J. Mol. Biol., 2005, 353, 38-52.

45 (a) T. Peters, Adv. Protein Chem., 1985, 37, 161-245; (b) Y.-Q. Wang, H.-M. Zhang, G.-C. Zhang, W.-H. Tao and S.-H. Tang, J. Lumin., 2007, 126, 211-218.
46 J. R. Lakowicz, Principles of Fluorescence Spectroscopy, Springer, New York, 3rd edn, 2006.

47 G. Scatchard, Ann. N. Y. Acad. Sci., 1949, 51, 660-672.

48 (a) J. Tang, F. Luan and X. Chen, Bioorg. Med. Chem., 2006, 14, 3210-3217; (b) J. N. Miller, Proc. Anal. Div. Chem. Soc., 1979, 16, 203-208.

49 N. Selvakumaran, N. S. P. Bhuvanesh, A. Endo and R. Karvembu, Polyhedron, 2014, 14, 95-109.

50 M. Y. Li, C. S. Cline, E. B. Koker, H. H. Carmichael, C. F. Chignell and P. Bilski, Photochem. Photobiol., 2001, 74, 760-764.

51 S. M. Klein, G. Cohen and A. I. Cederbaum, Biochemistry, 1981, 20, 6006-6012.

52 J. S. Beckman, T. W. Beckman, J. Chen, P. A. Marshall and B. A. Freeman, Proc. Natl. Acad. Sci. U. S. A., 1990, 87, 1620-1624.

53 (a) A. U. Khan, J. Phys. Chem., 1976, 80, 2219-2228; (b) P. B. Merkel and D. R. Kearns, J. Am. Chem. Soc., 1972, 94, 1029-1030.

54 D. D. Perrin, W. L. F. Armarego and D. R. Perrin, Purification of Laboratory Chemicals, Pergamon Press, Oxford, 1980.

55 L. R. Melby, N. J. Rose, E. Abramson and J. C. Caris, J. Am. Chem. Soc., 1964, 86, 5117-5125.

56 APEX2 v2012.4, Bruker AXS, Madison, WI, 1999.

57 N. Walker and D. Stuart, Acta Crystallogr., Sect. A: Found. Crystallogr., 1983, 39, 158-166.

58 G. M. Sheldrick, SADABS, Area Detector Absorption Correction, University of Göttingen, Göttingen, Germany, 2001.

59 G. M. Sheldrick, SHELX-97, Program for Refinement of Crystal Structures, University of Göttingen, Göttingen, Germany, 1997.

60 (a) G. M. Sheldrick, Acta Crystallogr., Sect. A: Found. Crystallogr., 2008, 64, 112-122; (b) G. M. Sheldrick, SHELXTL 6.14, Bruker, AXS Inc., Madison, WI, 2000.

61 (a) L. J. Farrugia, WINGX ver 1.70, An Integrated System of Windows Programs for the Solution, Refinement, and Analysis of Single Crystal X-ray Diffraction Data, Department of Chemistry, University of Glasgow, 2005; (b) L. J. Farrugia, J. Appl. Crystallogr., 1999, 32, 837-838.

62 M. N. Burnett and C. K. Johnson, ORTEP-III, Report ORNL6895, Oak Ridge National Laboratory, Oak Ridge, TN, 1996.

63 J. Marmur, J. Mol. Biol., 1961, 3, 208-218.

64 M. E. Reichmann, S. A. Rice, C. A. Thomas and P. Doty, J. Am. Chem. Soc., 1954, 76, 3047-3053.

65 A. Wolfe, G. H. Shimer and T. Meehan, Biochemistry, 1987, 26, 6392-6396.

66 M. Lee, A. L. Rhodes, M. D. Wyatt, S. Forrow and J. Hartley, Biochemistry, 1993, 32, 4237-4245.

67 T. Peters Jr, All About Albumin: Biochemistry, Genetics and Medical Applications, Academic Press, New York, 1995.

68 E. Alarcon, A. Aspee, M. Gonzalez-Bejar, A. M. Edwards, E. Lissi and J. C. Scaiano, Photochem. Photobiol. Sci., 2010, 9, 455-461. 